\title{
Slow-Adhering Stem Cells Derived from Injured Skeletal Muscle Have Improved Regenerative Capacity
}

\author{
Xiaodong Mu, ${ }^{\dagger}$ Guosheng Xiang, ${ }^{\dagger}$ \\ Christopher R. Rathbone, ${ }^{\mp}$ Haiying Pan, ${ }^{* \dagger}$ \\ Ian H. Bellayr, ${ }^{\star}$ Thomas J. Walters, ${ }^{\neq}$ \\ and Yong $\mathrm{Li}^{\star}+\S \uparrow$ \\ From the Laboratory of Molecular Pathology,* Stem Cell Research \\ Center, Children's Hospital of Pittsburgh, University of Pittsburgh \\ Medical Center, Pittsburgh, Pennsylvania; the Departments of \\ Orthopaedic Surgery, ${ }^{\dagger}$ Bioengineering, ${ }^{,}$and Pathology, ${ }^{\pi}$ \\ University of Pittsburgh, Pittsburgh, Pennsylvania; and the \\ Extremity Trauma and Regenerative Medicine Research \\ Program, ${ }^{\ddagger}$ United States Army Institute of Surgical Research, Fort \\ Sam Houston, Texas
}

A wide variety of myogenic cell sources have been used for repair of injured and diseased muscle including muscle stem cells, which can be isolated from skeletal muscle as a group of slow-adhering cells on a collagen-coated surface. The therapeutic use of muscle stem cells for improving muscle regeneration is promising; however, the effect of injury on their characteristics and engraftment potential has yet to be described. In the present study, slow-adhering stem cells (SASCs) from both laceration-injured and control noninjured skeletal muscles in mice were isolated and studied. Migration and proliferation rates, multidifferentiation potentials, and differences in gene expression in both groups of cells were compared in vitro. Results demonstrated that a larger population of SASCs could be isolated from injured muscle than from control noninjured muscle. In addition, SASCs derived from injured muscle demonstrated improved migration, a higher rate of proliferation and multidifferentiation, and increased expression of Notch1, STAT3, Msx1, and MMP2. Moreover, when transplanted into dystrophic muscle in MDX/SCID mice, SASCs from injured muscle generated greater engraftments with a higher capillary density than did SASCs from control noninjured muscle. These data suggest that traumatic injury may modify stem cell characteristics through trophic factors and improve the transplantation potential of SASCs in alleviating skeletal muscle injuries and diseases. (Am J Pathol 2011, 179:931-941; DOI: 10.1016/j.ajpath.2011.05.004)
The normal repair of adult skeletal muscle after injury relies on activation and proliferation of resident stem cells, including satellite cells, which are myogenic precursor cells that reside beneath the basal lamina of muscle fibers and replace lost myonuclei. ${ }^{1}$ The limited migratory capacity and survival of satellite cells and myoblasts when transplanted into injured or diseased muscle have led researches to identify other stem cell sources to achieve a therapeutic effect ${ }^{2}$ including stem cells in skeletal muscle, which are multipotent and nonlineage-committed and may potentially be of perivascular origin. ${ }^{3-5}$

Among these muscle precursors, muscle-derived stem cells (MDSCs) exist in normal muscle as a small population that usually expresses specific stem cell markers such as Sca-1 and CD34. ${ }^{6-9}$ Isolation of MDSCs has been widely performed using a marker profile-independent preplate technique that takes advantage of their slow adherence to a collagen-coated surface, $, 6,7,9,10$ and MDSCs are included in a population of slow-adhering stem cells (SASCs) isolated with this technique. Using MDSCs for tissue engineering application and cell transplantation into animals and patients has verified that these cells are highly efficient for stem cellbased therapies in various tissues including regeneration and repair of skeletal and cardiac muscle, bone, articular cartilage, and peripheral nerve. ${ }^{8,11-19}$ However, previous studies have been limited to SASCs isolated from healthy noninjured skeletal muscle, and SASCs from injured muscle have not as yet been characterized.

Various injuries or stimuli to skeletal muscle may alter the microenvironment of resident muscle cells (ie, stimulating cell dedifferentiation on various trophic factors) $)^{20,21}$ and result in profound changes to the phenotypes of many cells including muscle stem cells. For example,

Supported in part by grants from the National Institutes of Health and the US Department of Defense (Y.L.).

Accepted for publication May 2, 2011.

The opinions or assertions contained herein are the private views of C.R.R. and T.J.W. and are not to be construed as official or as reflecting the views of the US Department of the Army or the US Department of Defense.

Address reprint requests to Yong Li, M.D., Ph.D., Laboratory of Molecular Pathology, Stem Cell Research Center, University of Pittsburgh Medical Center, Office 217, Bridgeside Point II, 450 Technology Dr., Pittsburgh, PA 15219. E-mail: yongli@pitt.edu. 
CD45-positive muscle stem cells usually have low myogenic potential in healthy muscle but have greatly improved myogenic potential in injured muscle as a result of modified Wnt signaling. ${ }^{21}$ In addition, an increased number of myogenic precursor cells have been isolated from injured muscle. ${ }^{22}$ Because of the greatly increased number of muscle precursor cells in injured muscle, it is rational to hypothesize that there are more SASCs in injured muscle. However, the different characteristics of SASCs isolated from injured muscle and control noninjured muscle have not been investigated, and, in addition, the effect of injury on the usefulness of SASCs for transplantation remains to be determined.

In the present study, using a modified preplate technique [preplate population 6 (PP6)], ${ }^{7}$ a group of SASCs were isolated from injured and healthy noninjured mouse gastrocnemius muscle at 4 days after laceration injury, which is when muscle stem cells undergo activation and proliferation. ${ }^{23,24}$ Studies were then performed to directly compare the various characteristics of SASCs isolated from injured muscle and control noninjured muscle including the ratio of cells positive for Sca-1 and those positive for CD34 (MDSCs), and potential for cell migration, proliferation, and multidifferentiation. To verify the regenerative capacity of isolated SASCs from noninjured and injured muscle, their efficiency in repairing dystrophic muscle was compared in MDX mice, a murine model that represents Duchenne's muscular dystrophy in human beings. ${ }^{25}$ In addition, to understand the molecular mechanisms underlying the modified characteristics of SASCs after muscle injury, mRNA levels of several important genes were compared relative to stem cell multipotency, muscle development, and muscle regeneration.

\section{Materials and Methods}

\section{Muscle Injury}

The use of animals and the surgical procedures performed in this study were approved by the Institutional Animal Care and Use Committee of the University of Pittsburgh Medical Center. The gastrocnemius muscle in one leg of mice (male C57BL/6J aged 4 weeks; Jackson Laboratory, Bar Harbor, $\mathrm{ME})$ received a laceration injury, as described previously, ${ }^{26}$ and the gastrocnemius muscle in the other leg served as the control noninjured muscle.

\section{Isolation of SASCs Using a Modified Preplate Technique}

Four days after laceration injury, both injured and noninjured gastrocnemius muscles (equal mass) were harvested for cell isolation. Using a modified preplate technique, ${ }^{7}$ different preplate populations (PP1 to PP6) of cells with various adhering characteristics on collagencoated flasks were separated. The early preplate populations (rapid-adhering cells, ie, PP1 and PP2) contain primarily fibroblasts and myoblasts, whereas the late preplate populations (slow-adhering cells, ie, PP5 and PP6) contain primarily muscle stem cells including MDSCs. ${ }^{7}$
PP6 cells (SASCs that contain MDSCs) were studied, and PP6 cells from both noninjured and injured muscles were cultured in proliferation medium [Dulbecco's modified Eagle's medium (DMEM); Invitrogen Corp., Carlsbad, CA] supplemented with $10 \%$ horse serum, $20 \%$ fetal bovine serum, $0.5 \%$ chicken embryo extract, and $1 \%$ penicillin-streptomycin] in $5 \% \mathrm{CO}_{2}$ at $37^{\circ} \mathrm{C}$.

\section{In Vitro Wound Healing Study}

SASCs from noninjured or injured muscles were seeded in collagen-coated 12-well plates in proliferation medium. When cells reached approximately $85 \%$ confluency, artificial wounds were generated, as described previously, ${ }^{27,28}$ in the cells in proliferation medium. After 6 hours, the migration distance (in microns) of SASCs into the wounded area was measured.

\section{Cell Proliferation Assay Using EdU}

The Click-iT EdU cell proliferation assay (Invitrogen Corp., Carlsbad, CA) was performed to verify the proliferation potential of isolated SASCs, as instructed by the manufacturer's protocol. In brief, SASCs from noninjured or injured muscles were seeded in collagen-coated 12well plates (5000 cells per well) and grown in proliferation medium containing $0.1 \%$ EdU (5-ethynyl-2'-deoxyuridine). After 16 hours, cells were fixed, and a speciesspecific secondary antibody (Alexa Fluor 594, 1:400; Invitrogen Corp.) was used for EdU detection. DAPI counterstaining was conducted to visualize cell nuclei.

\section{Population-Doubling Analysis}

Population-doubling analysis was performed as described previously. ${ }^{20}$ SASCs from noninjured and injured muscle were individually plated $\left(1 \times 10^{3}\right.$ cells per well) in a collagen-coated six-well plate and cultured in proliferation medium. SASCs were then cultured continuously for 48 hours before being harvested and counted. The approximate population-doubling time was determined as follows: $2^{n}=$ Cell number at harvest time/Cell number initially plated, where $n$ is the number of doublings during the period of cell culture (48 hours). Thus, populationdoubling time $=48$ hours $/ \mathrm{n}$.

\section{Immunofluorescence Staining of Cells and Tissue Sections}

Cultured cells were fixed with $4 \%$ paraformaldehyde for 10 minutes, and skeletal muscle cryosections were fixed with $5 \%$ formalin for 10 minutes. After washing the samples with PBS, $10 \%$ horse serum was used to block nonspecific binding for 1 hour. The primary antibodies used were myosin heavy chain (No. M4276; Sigma-Aldrich Corp., St. Louis, MO; 1:200), p21 (No. 554085; Santa Cruz Biotechnology, Inc., Santa Cruz, CA; 1:200), Pax7 (No. Pax 7-c; Developmental Studies Hybirdoma Bank, lowa City, IA; 1:100), CD31 (No. 553370; BD Biosciences, San Jose, CA; 1:200), Sca-1 (No. 557403; BD Biosciences; 1:200), CD34 (No. 
553731; BD Biosciences; 1:200), and dystrophin (No. 15277; Abcam Inc., Cambridge, MA; 1:200). Secondary antibodies included Alexa Fluor 488 or 594 specific to various species (Invitrogen Corp.; 1:400). DAPI counterstaining was performed to visualize cell nuclei. Fluorescence microscopy (Leica Microsystems Inc., Bannockburn, IL) was used to examine all immunofluorescence results and to obtain photographic images.

\section{Flow Cytometry Assay of Stem Cell Markers}

SASCs $\left(1 \times 10^{5}\right)$ isolated from noninjured or injured muscle were collected and washed twice with sterile PBS. In the presence of $10 \%$ mouse serum to block nonspecific binding, PP6 cells were immunostained with phycoerythrin-conjugated antibody to Sca-1 (No. 553336; BD Biosciences; $1 \mu \mathrm{L}$ antibody per $10^{5}$ cells) and allophycocyanin-conjugated antibody to CD34 (No. 340667; BD Biosciences; $1 \mu \mathrm{L}$ antibody per $10^{5}$ cells) for 30 minutes on ice. Cells were then washed with sterile PBS three times for 10 minutes each before analysis using a FACSCalibur flow cytometer and Cell Quest software (both from BectonDickinson \& Co., San Jose, CA).

\section{In Vitro Myogenic Differentiation Assay}

SASCs from noninjured and injured muscle were cultured in proliferation medium to $85 \%$ confluency and changed to differentiation medium (DMEM supplemented with $2 \%$ horse serum and $1 \%$ penicillin-streptomycin) for myotube formation. Cells were incubated in $5 \% \mathrm{CO}_{2}$ at $37^{\circ} \mathrm{C}$ for 4 days before being fixed with $4 \%$ paraformaldehyde. The myotubes were identified by expression of fast-type myosin heavy-chain to show the proceeding stages of differentiation.

\section{In Vitro Osteogenic Differentiation Assay}

The osteogenic differentiation assay was performed as described previously. ${ }^{29,30}$ SASCs from noninjured and injured muscle were plated in six-well plates $\left(0.2 \times 10^{5}\right.$ cells per well) to allow for attachment. After 24 hours, the medium was replaced with osteogenic medium [DMEM supplemented with $0.1 \mu \mathrm{mol} / \mathrm{L}$ dexamethasone, 50 $\mu \mathrm{mol} / \mathrm{L}$ ascorbate-2-phosphate, and $10 \mathrm{mmol} / \mathrm{L} \beta$-glycerophosphate (all from Sigma-Aldrich Corp., St. Louis, MO), and $100 \mathrm{ng} / \mathrm{mL}$ BMP4 (R\&D Systems, Inc., Minneapolis, MN)]. The medium was changed every 2 days. Osteogenesis was assessed by observation of alkaline phosphatase activity at 5 days after initial osteogenic induction using an alkaline phosphatase kit (Sigma-86c; Sigma-Aldrich Corp.).

\section{In Vitro Adipogenic Differentiation Assay}

The adipogenic differentiation assay was performed as described previously. ${ }^{29,30}$ SASCs from noninjured and injured muscle were plated in six-well plates $\left(0.2 \times 10^{5}\right.$ cells per well) to allow for attachment. After 24 hours, the medium was replaced with adipogenic medium (highglucose DMEM supplemented with $10 \mu \mathrm{mol} / \mathrm{L}$ insulin, 1 $\mu \mathrm{mol} / \mathrm{L}$ dexamethasone, $0.5 \mathrm{mmol} / \mathrm{L}$ isobutylmethylxanthine, and $200 \mu \mathrm{mol} / \mathrm{L}$ indomethacin (all from SigmaAldrich Corp.). Cultures were maintained for 10 days, and the medium was changed every 2 days. The cultures were then stained with Oil Red O (Sigma-Aldrich Corp.), which indicates the intracellular lipid accumulation. After being fixed for 10 minutes at room temperature in $5 \%$ neutral buffered formalin, cells were rinsed with $60 \%$ isopropanol and incubated with a newly filtered Oil Red O staining solution for 20 minutes at room temperature. After staining, the cells were rinsed with double-distilled water and stored at $4^{\circ} \mathrm{C}$.

\section{In Vivo Assay of Regenerative Potentials of SASCs in Dystrophic Muscle}

SASCs from noninjured and injured muscle $\left(1 \times 10^{5}\right.$ cells per group) suspended in $10 \mu \mathrm{L}$ PBS were transplanted into the gastrocnemius muscles of MDX/SCID mice (dystrophic or immunodeficient, C57BL/10 ScSn-Dmdmdx crossed with C57BL/6J-Prkdcscid/SzJ; Jackson Laboratory) by direct injection into the gastrocnemius muscles of the left and right legs, respectively. Four MDX/SCID mice

Table 1. Primers for RT-PCR

\begin{tabular}{|c|c|c|c|}
\hline Gene & GenBank accession no. & Primer sequence & Product size (bp) \\
\hline Notch1 & NM_008714 & $\begin{array}{l}\text { Forward: 5'-GCCGCAAGAGGCTTGAGAT-3' } \\
\text { Reverse: 5'-GGAGTCCTGGCATCGTTGG-3' }\end{array}$ & 129 \\
\hline STAT3 & BC003806 & $\begin{array}{l}\text { Forward: 5'-CAATACCATTGACCTGCCGAT-3' } \\
\text { Reverse: 5'-GAGCGACTCAAACTGCCCT-3' }\end{array}$ & 109 \\
\hline Ms $\times 1$ & NM_010835 & $\begin{array}{l}\text { Forward: 5'-CCTCTCGGCCATTTCTCAGT-3' } \\
\text { Reverse: 5'-TTGCGTAGGGTGCATGCTG-3' }\end{array}$ & 163 \\
\hline Pax3 & NM_008781 & $\begin{array}{l}\text { Forward: 5'-TCCGAGCACTGTACACCAAAGC-3' } \\
\text { Reverse: 5'-CGATGGAGGCACAAAGCTGTCT-3' }\end{array}$ & 118 \\
\hline Pax7 & NM_011039 & $\begin{array}{l}\text { Forward: 5'-TCTCCAAGATTCTGTGCCGAT-3' } \\
\text { Reverse: 5'-CGGGGTTCTCTCTCTTATACTCC-3' }\end{array}$ & 132 \\
\hline MMP2 & NM_008610 & $\begin{array}{l}\text { Forward: 5'-ATCAAGGGGATCCAGGAGC-3' } \\
\text { Reverse: 5'-GCAGCGATGAAGATGATAG-3' }\end{array}$ & 718 \\
\hline MMP9 & NM_013599 & $\begin{array}{l}\text { Forward: 5'-TGTTCAGCAAGGGGCGTGTC-3' } \\
\text { Reverse: 5'-AAACAGTCCAACAAGAAAGG-3' }\end{array}$ & 458 \\
\hline GAPDH & NM_008084 & $\begin{array}{l}\text { Forward: 5'-CCTCTGGAAAGCTGTGGCGT-3' } \\
\text { Reverse: } 5 \text { '-TTGGCAGGTTTCTCCAGGCG-3' }\end{array}$ & 190 \\
\hline
\end{tabular}



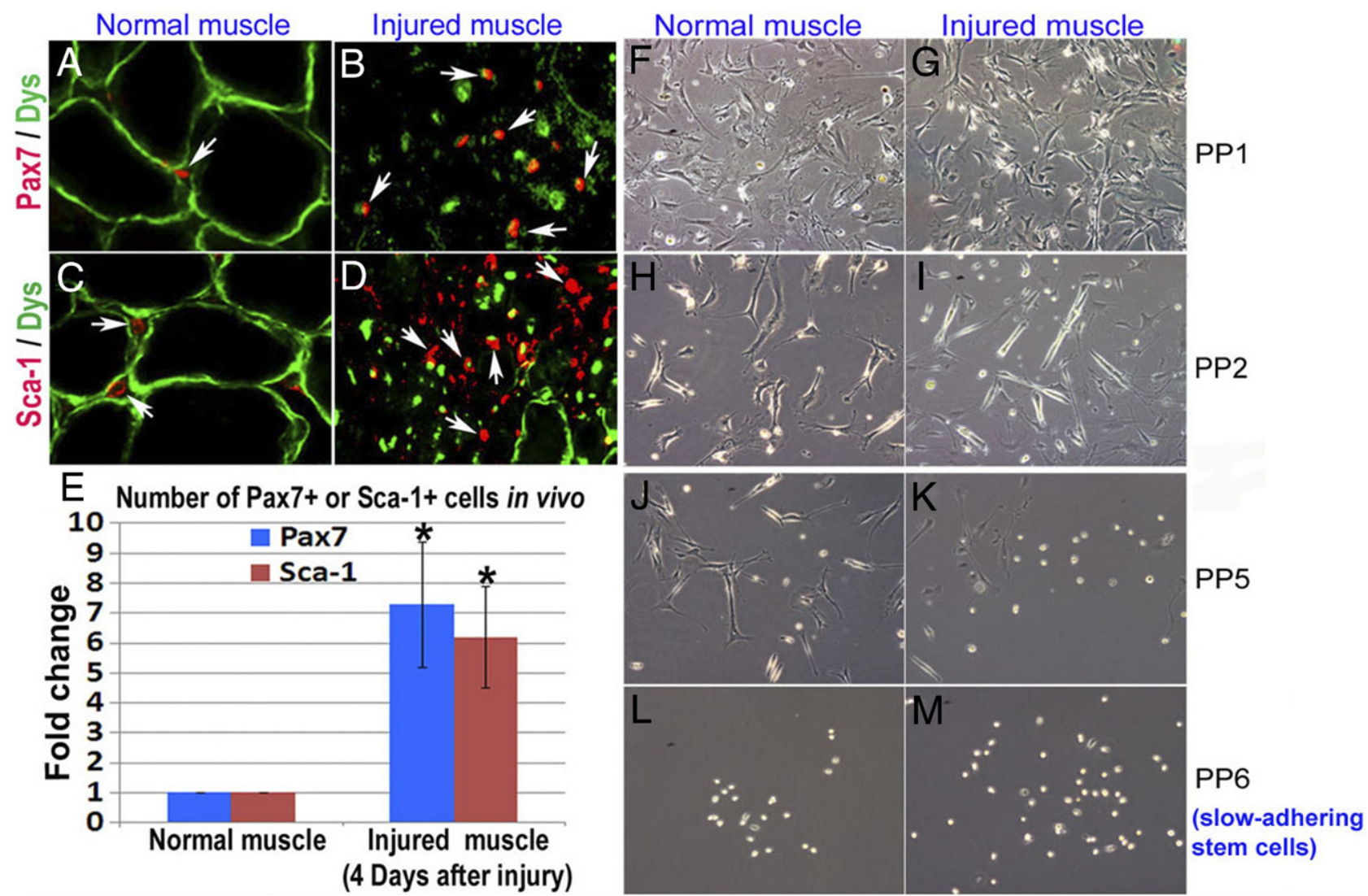

Figure 1. Stem cell populations increased in mouse skeletal muscle after injury. A-D: Four days after muscle laceration-injury, the number of cells positive for Pax7 and Sca-1 increased in vivo, as shown at IHC staining. E: Statistical analysis of the number of cells positive for Pax7 and Sca-1. F-M: Using a preplate technique, different populations were isolated from injured skeletal muscle and control noninjured muscle, according to the adhering characteristic of the cells. ${ }^{7}$ Based on our knowledge, the fast-adhering PP1 populations are generally fibroblasts (F and G), and PP2 populations are generally myoblasts (H and $\mathbf{I}$ ); slow-adhering PP5 populations contain many satellite cells ( $\mathbf{J}$ and $\mathbf{K}$ ), and PP6 populations contain many MDSCs (L and $\mathbf{M}){ }^{7}$ Many more spherical and refractive stem cell-shaped cells were observed in the PP6 population (SASCs) from injured muscle (M) compared with control noninjured muscle (L) (approximately 1:4, respectively). E: Asterisk indicates that the value is significantly different from that of control noninjured muscle $(P<0.05)$.

were used for cell transplantation in this experiment, and their muscle tissues were harvested for cryosectioning and histologic analysis at 3 weeks after cell transplantation. The myogenic differentiation capacity was determined by measuring the number of regenerating dystrophin-positive myofibers. The number of regenerating dystrophin-positive myofibers were counted on three different cross-sections from each injected muscle. The site that was identified as the injection site was counted because the cells were injected at only one location, where it generated a limited area of myofiber engraftment. In addition, CD31-positive capillary density (CD31-positive capillary structures per highpower field) was measured in the area of cell engraftment.

\section{Semiquantitative RT-PCR}

Total RNA was obtained from SASCs using the RNeasy Mini Kit (Qiagen, Inc., Valencia, CA) according to the manufacturer's instructions. Reverse transcription was performed using the iScript cDNA Synthesis Kit (Bio-Rad Laboratories, Inc., Hercules, CA). The sequences of primers are given in Table 1, including Notch1 [Notch homolog 1, translocation-associated (Drosophila)], STAT3 (signal transducers and activators of transcription 3), Msx1 (muscle segment homeobox transcription factor 1), Pax3 and Pax7 (paired box proteins 3 and 7), MMP2 and MMP9 (matrix metalloproteinases 2 and 9), and GAPDH (glyceraldehyde 3-phosphate dehydrogenase). PCR reactions were performed using an iCycler Thermal Cycler (Bio-Rad Laboratories, Inc.). The cycling parameters used for all primers were as follows: $95^{\circ} \mathrm{C}$ for 10 minutes; PCR, 40 cycles of 30 seconds at $95^{\circ} \mathrm{C}$ for denaturation, 1 minute at $53^{\circ} \mathrm{C}$ to $62^{\circ} \mathrm{C}$ for annealing, and 30 seconds at $72^{\circ} \mathrm{C}$ for extension. Products were separated by size, and were visualized on $1.5 \%$ agarose gel stained with ethidium bromide. All data were normalized to the expression of GAPDH.

\section{Measurement of Results and Statistical Analysis}

The measurement of results from images was performed using commercially available software (Northern Eclipse, version 6.0; Empix Imaging, Inc., Mississauga, ON, Canada) and Image J software (version 1.32j; National Institutes of Health, Bethesda, MD). Data from at least three samples from each subject were pooled for statistical analysis. Results are given as mean \pm SE. The difference between means was considered statistically significant at $P<0.05$. Analysis of variance was used in conjunction with a post hoc test (Dunnett's test as error protection) to compare the difference between groups of cells or tissue sections. 


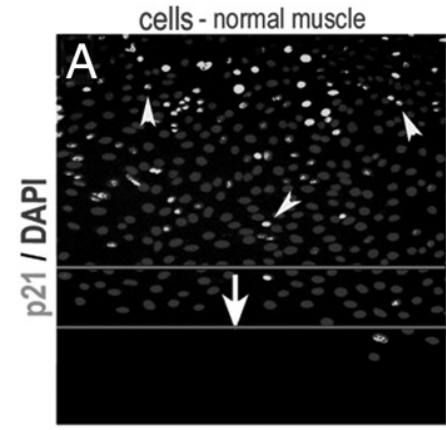

\begin{abstract}
cells - injured muscle
\end{abstract}
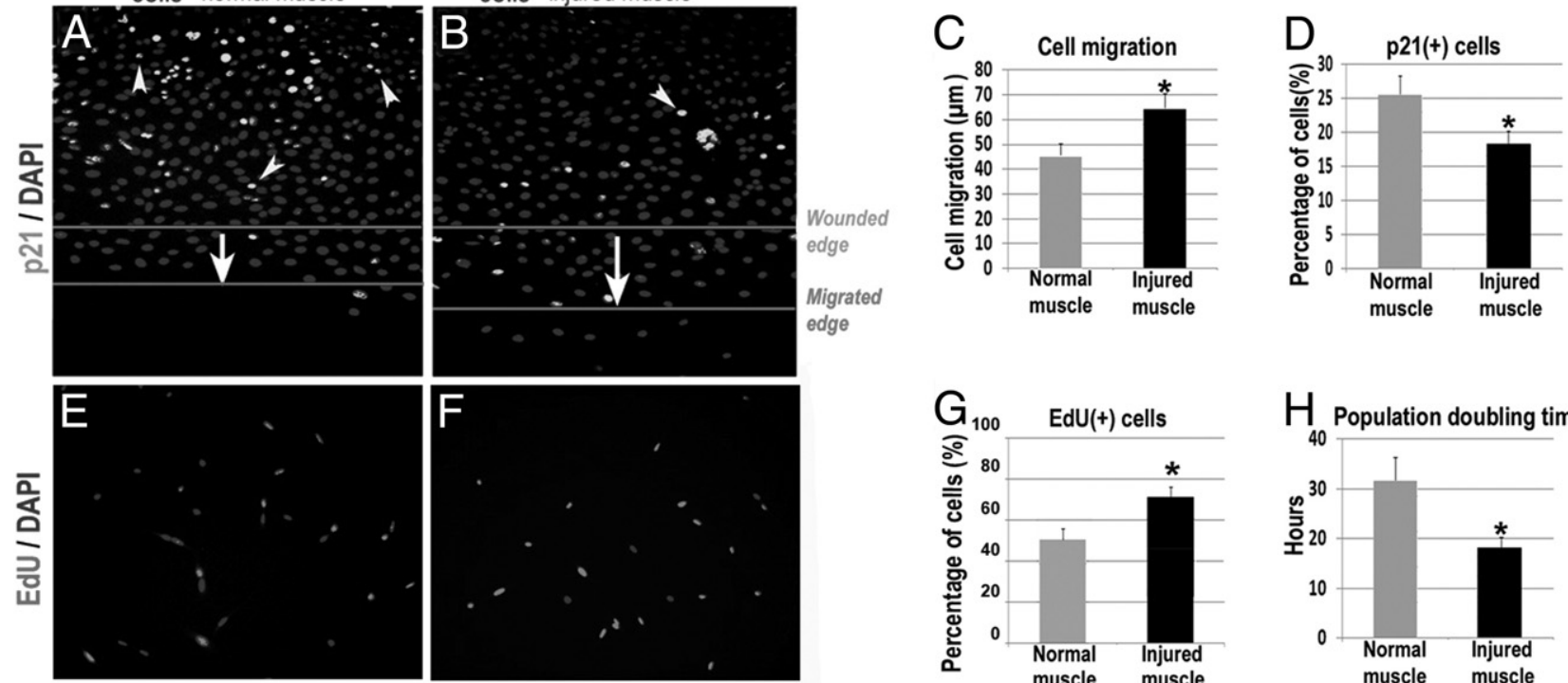
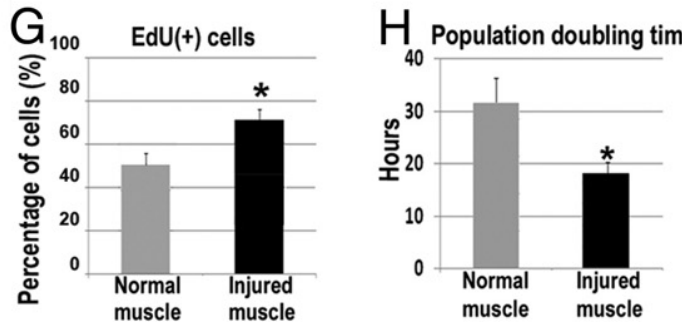

Figure 2. Isolated SASCs from injured skeletal muscle have improved migration and proliferation capacities. A-D: Compared with cells isolated from control noninjured skeletal muscle, SASCs from injured muscle migrated more quickly in an in vitro would healing assay (C); deposition of p21 (arrowheads), which is essential for normal myogenic progenitor cell function in regeneration, ${ }^{34}$ was reduced in cells from injured muscle (D). E-G: Cell proliferation potential was tested using the EdU assay, and a higher ratio of EdU-positive cells was observed in SASCs from injured muscle (G). H: In a population-doubling assay, SASCs from injured muscle demonstrated shorter population-doubling time compared with those isolated from control noninjured skeletal muscle. Data in graphs $\mathbf{C}$ and $\mathbf{D}$ are from counting of cells with positive signal in images $\mathbf{A}$ and $\mathbf{B}$, data in graph $\mathbf{G}$ are from counting of immunofluorescence-positive cells in images $\mathbf{E}$ and $\mathbf{F}$, and data in graph $\mathbf{H}$ are from a population-doubling assay. $\mathbf{C}, \mathbf{D}, \mathbf{G}$ and $\mathbf{H}$ : Asterisk indicates that the value is significantly different from that of control noninjured muscle $(P<0.05)$.

\section{Results}

\section{Larger Population of Muscle Stem Cells Observed in Both Injured Muscle in Vivo and Isolated Muscle Cells in Vitro}

In the laceration-injured skeletal muscle mouse model, a significantly larger population of muscle stem cells was observed at 4 days after the injury (Figure 1, A-E) and included both Pax7-positive satellite cells ${ }^{31}$ (Figure 1, A and $B$ ) and Sca-1-positive muscle stem cells ${ }^{7,32}$ (Figure $1, C$ and D). A preplate technique was used to isolate SASCs from both noninjured and injured muscles. Results demonstrated that the fast-adhering cells from both noninjured and injured muscles exhibited structural features similar to those of fibroblasts or myoblasts ${ }^{7,9}$ (PP1 and PP2; Figure 1, F-I). The slow-adhering cell populations from both muscle types generally contained many cells with structural features similar to those of stem cells (spherical and refractive) (PP5 and PP6; Figure 1, J-M). The population of PP6 cells, which are SASCs, ${ }^{7,9}$ was much more enriched in cells isolated from injured muscle than from noninjured muscle (Figure 1, L and M). Therefore, these results indicate that using the modified preplate technique, a much larger number of SASCs can be efficiently isolated and expanded from injured muscle than from noninjured muscle.

\section{SASCs from Injured Muscle Demonstrate Improved Migration and Proliferation Capacities}

During the muscle healing process, improved migration and proliferation capacities are necessary for activated muscle precursor cells to efficiently participate in muscle regeneration. ${ }^{23,24}$ We investigated whether SASCs isolated from injured muscle also exhibit these characteristics. To compare the migration capacity of the cells, an in vitro wound healing assay was performed as described previously. ${ }^{27}$ Results demonstrated that at 6 hours after creation of the wound, SASCs from injured muscle had migrated farther into the wounded area than did SASCs from noninjured muscle (Figure 2, A-C). Immunofluorescence staining demonstrated that the protein level of cyclin-dependent kinase inhibitor p21, an inhibitor of the cell cycle that is essential for coordination of exiting the cell cycle and differentiation of myogenic progenitor cells, ${ }^{33,34}$ was greatly reduced in SASCs from injured muscle compared with SASCs from noninjured muscle (Figure 2A, B, and D). The repressed p21 activity in the SASCs from injured muscle may suggest withdrawal from quiescence and an increased proliferation potential of the cells. ${ }^{35,36}$ Indeed, SASCs isolated from noninjured muscle usually maintain their quiescence during the first week and begin proliferation during the second week $^{7}$; however, SASCs from injured muscle seem to be activated and proliferate from the first week of culture because more cells could be isolated (Figure 1M). This observation of SASCs is similar to the previously reported observation of satellite cells that features an increase in activation and proliferation after muscle injury. ${ }^{1}$ To further verify the proliferation capacity of SASCs, cell proliferation was analyzed using the EdU proliferation assay and the population-doubling assay. Results demonstrated that SASCs from injured muscle exhibited a significantly higher rate of EdU incorporation during 16 hours of culture (Figure 2, E-G) and reduced population-doubling 

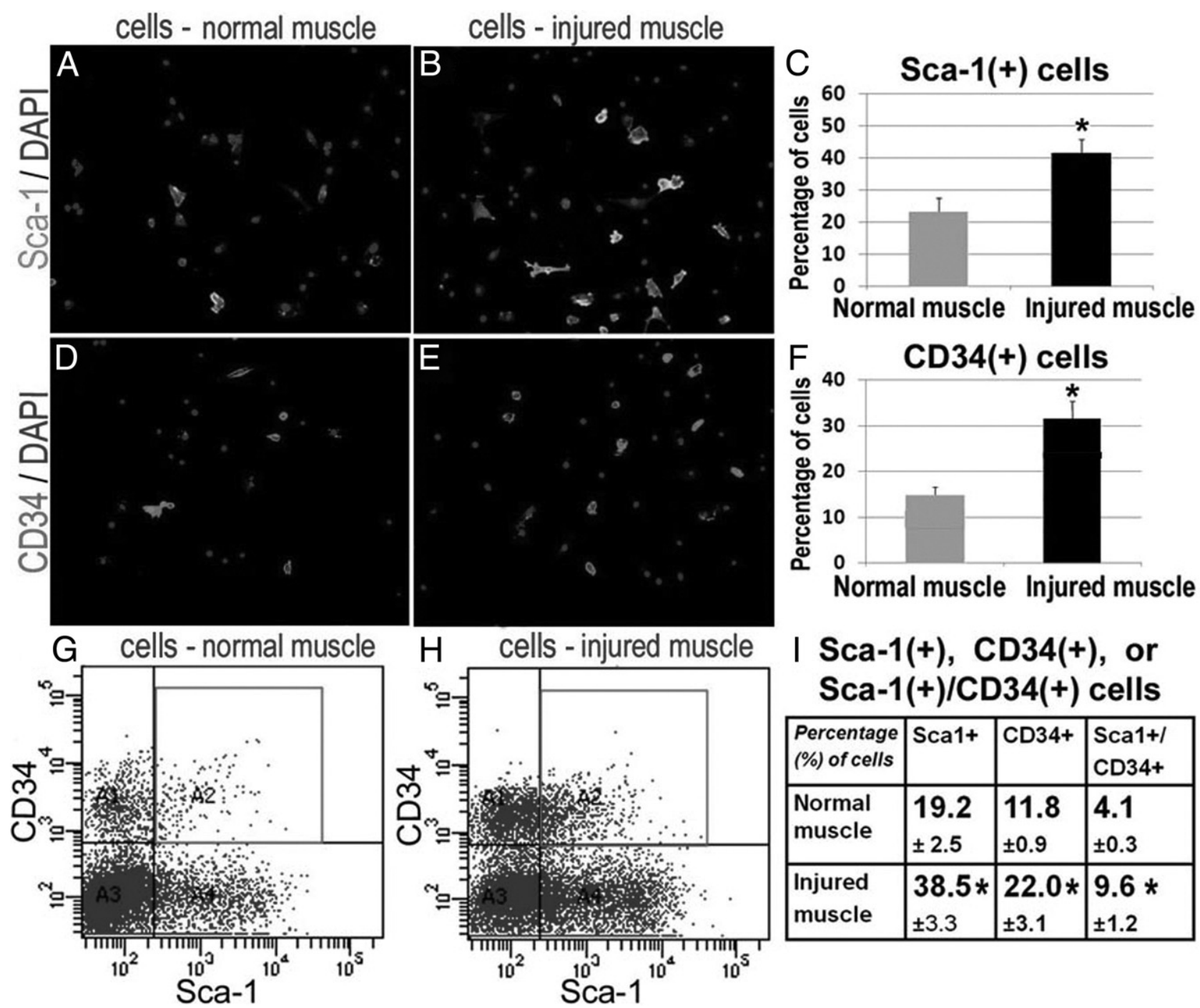
I Sca-1(+), CD34(+), or Sca-1(+)/CD34(+) cells

\begin{tabular}{|l|l|l|l|}
\hline $\begin{array}{l}\text { Percentage } \\
(\%) \text { of cells }\end{array}$ & Sca1+ & CD34+ & $\begin{array}{l}\text { Sca1+l } \\
\text { CD34+ }\end{array}$ \\
\hline $\begin{array}{l}\text { Normal } \\
\text { muscle }\end{array}$ & $\begin{array}{l}19.2 \\
\pm 2.5\end{array}$ & $\begin{array}{l}11.8 \\
\pm 0.9\end{array}$ & $\begin{array}{l}4.1 \\
\pm 0.3\end{array}$ \\
\hline $\begin{array}{l}\text { Injured } \\
\text { muscle }\end{array}$ & $\begin{array}{l}38.5 * \\
\pm 3.3\end{array}$ & $\begin{array}{l}22.0 * \\
\pm 3.1\end{array}$ & $\begin{array}{l}9.6 * \\
\pm 1.2\end{array}$ \\
\hline
\end{tabular}

Figure 3. SASCs isolated from injured skeletal muscle contain more populations positive for Sca-1 and CD34. A-F: Immunocytochemistry demonstrated that SASCs isolated from injured muscle contain more cells positive for Sca-1 (B) and CD34 (E) compared with those isolated from control noninjured muscle (A and D). G-I: SASCs isolated from both injured and control noninjured muscle were analyzed using flow cytometry for the immunofluorescent signal of Sca-1 and CD34. Results demonstrated that the percentage of cells positive for Sca-1, CD34, or both was much greater in SASCs isolated from injured muscle (H and $\mathbf{I}$ ) compared with those from control noninjured muscle ( $\mathbf{G}$ and $\mathbf{I})$. Data in graphs $\mathbf{C}$ and $\mathbf{F}$ are from counting of immunofluorescence-positive cells in $\mathbf{A}$ and $\mathbf{B}$ and $\mathbf{D}$ and $\mathbf{E}$, respectively, and data in graph $\mathbf{I}$ are from comparing results in $\mathbf{G}$ and $\mathbf{H}$. $\mathbf{C}, \mathbf{F}$ and $\mathbf{I}$ : Asterisk indicates that the value is significantly different from that of the control noninjured muscle $(P<0.05)$.

time (Figure $2 \mathrm{H}$ ), which demonstrated that these cells have improved proliferation capacity compared with cells from noninjured muscle.

\section{SASCs from Injured Muscle Contain a Higher Ratio of Sca-1-Positive to CD34-Positive Cells (MDSCs)}

The differential expression of various stem cell markers between SASCs from noninjured and injured muscle was compared including endothelial cell marker CD31, ${ }^{37}$ hematopoietic cell marker CD45, ${ }^{38}$ and MDSC markers Sca-1 and CD34. ${ }^{6-8}$ Results of immunocytochemistry demonstrated that both CD31- and CD45-positive cells were undetectable in SASCs from either noninjured or injured muscles, which indicates that there is almost no presence of lineage-determined endothelial cells or hematopoietic cells in either group of isolated SASCs. However, compared with SASCs from noninjured muscle, the populations of cells positive for Sca-1 (Figure 3, A-C) and CD34 (Figure 3, D-F) were both greatly increased in SASCs from injured muscle. Results of flow cytometry further verified Sca-1 and CD34 expression in isolated SASCs, and a greater percentage of cells were positive for Sca-1, CD34, or both in SASCs from injured muscle compared with those from noninjured muscle (Figure 3, G-I). Cells positive for Sca-1 and CD34 cells belong to MDSCs, and are highly proliferative, multipotent, and regenerative. ${ }^{7,8}$ The enrichment of MDSCs in SASCs from injured muscle may suggest improved multidifferentiation and regenerative potential of the cell population compared with SASCs from noninjured muscle. 


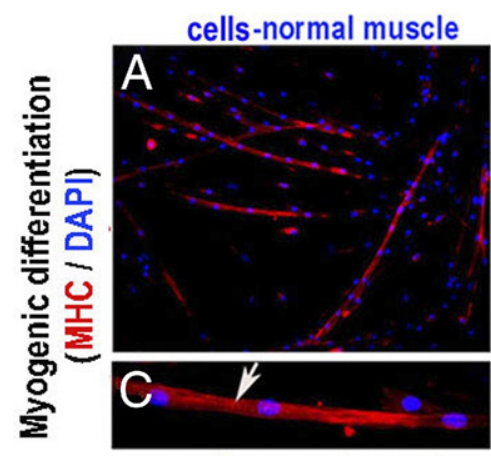

cells-normal muscle
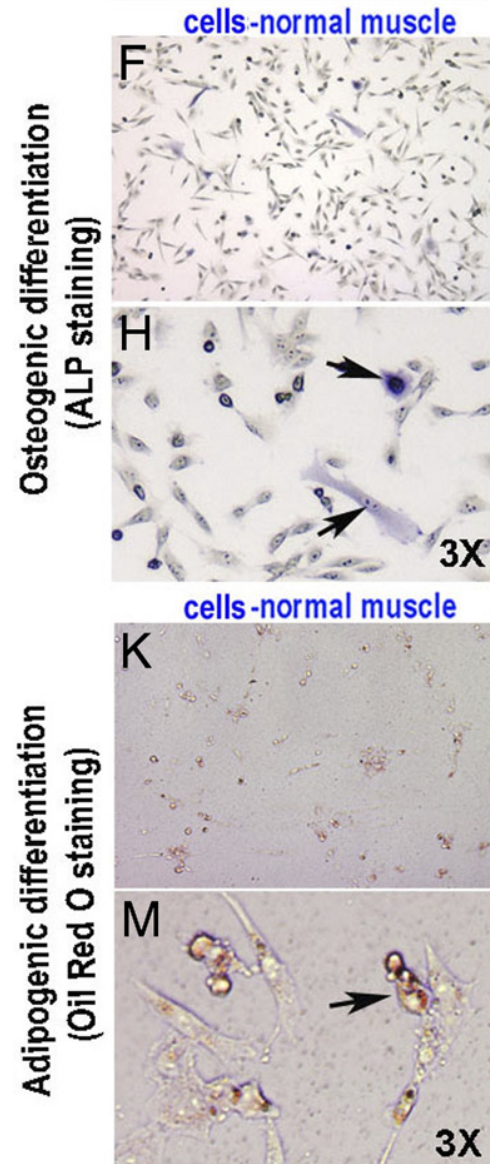

cells -injured muscle

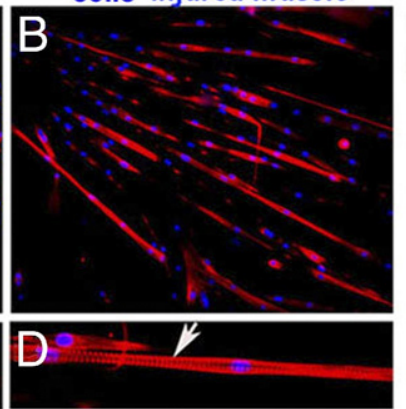

cells-injured muscle
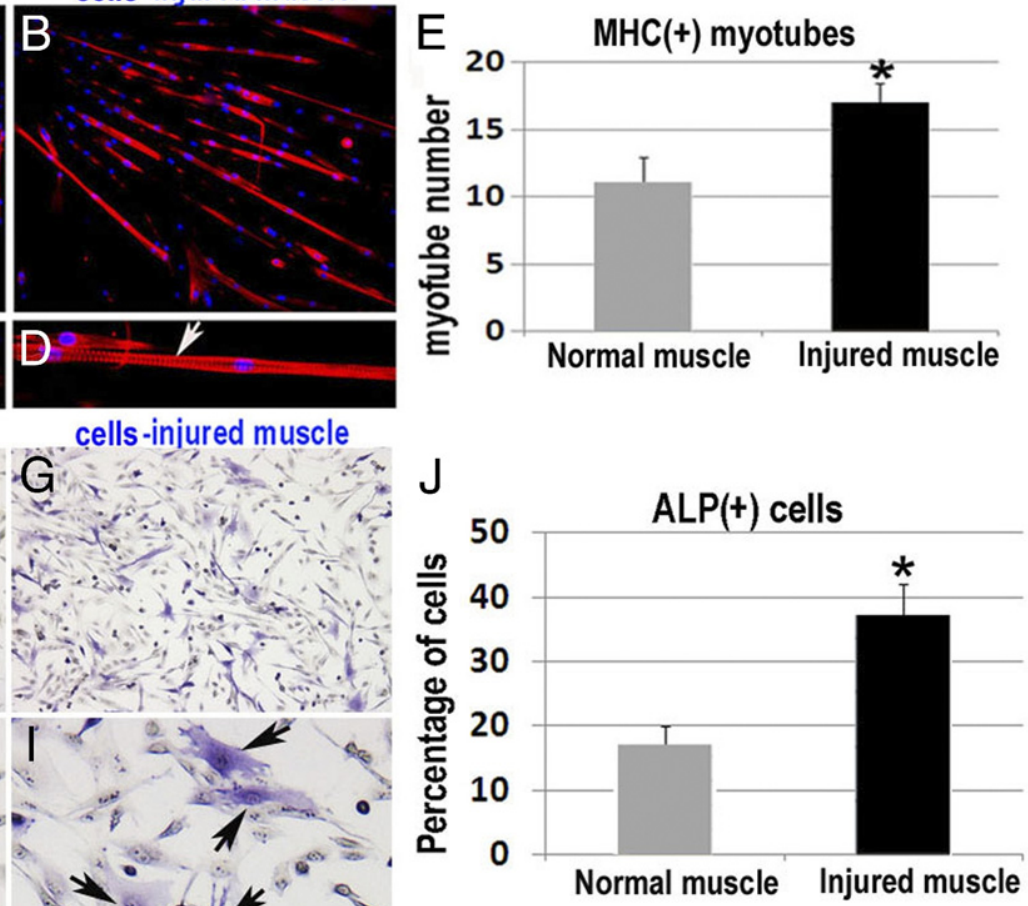

Figure 4. SASCs isolated from injured skeletal muscle underwent more efficient myogenic, osteogenic, and adipogenic differentiation in vitro. A-E: In vitro myogenic assay demonstrated that SASCs isolated from injured muscle formed more myotubes positive for myosin heavy chain after 4 days of myogenic induction (B) compared with those isolated from control noninjured skeletal muscle (A). A clearer striated pattern of myosin heavy chain in myotubes formed by SASCs isolated from injured muscle was also observed (D) compared with the control group (C). F-J: In an in vitro osteogenesis assay, detection of alkaline phosphatase activity demonstrated that SASCs isolated from injured muscle generated an increased number of cells positive for alkaline phosphatase (G and I) compared with control groups $(\mathbf{F}$ and $\mathbf{H}$ ) after 1 week of osteogenic induction. $\mathbf{K}-\mathbf{O}$ : Similarly, in an in vitro adipogenesis assay, Oil Red O staining demonstrated that SASCs isolated from injured muscle generated an increased number of adipose-like cells positive for oil droplets (L and $\mathbf{N}$ ) compared with control groups (K and $\mathbf{M}$ ). Data in graphs $\mathbf{E}, \mathbf{J}$, and $\mathbf{O}$ are from counting of cells with positive signal in images $\mathbf{A}$ and $\mathbf{B}, \mathbf{F}$ and $\mathbf{G}$, and $\mathbf{K}$ and $\mathbf{L}$, respectively. $\mathbf{E}, \mathbf{J}$, and $\mathbf{O}$ : Asterisk indicates that the value is significantly different from that of control noninjured muscle $(P<0.05)$.

\section{SASCs from Injured Muscle Demonstrate Improved Myogenic, Osteogenic, and Adipogenic Differentiation Potential in Vitro}

To further verify the improved multipotency of SASCs from injured muscle, in vitro myogenic, osteogenic, and adipogenic assays were performed. The results of the myogenic assay demonstrated that at 4 days after induction of myogenic differentiation (serum deprivation),
SASCs from injured muscle produced more myotubes positive for myosin heavy-chain than did SASCs from noninjured muscles (Figure 4, A and B). Meanwhile, myotubes positive for myosin heavy chain produced by SASCs from injured muscle exhibited a clearly striated pattern (Figure 4, C and D), a feature of mature functional myofibers in skeletal muscle. ${ }^{39}$ Alkaline phosphatase staining and Oil Red O staining were performed to demonstrate the outcomes of osteogenic and adipogenic dif- 
cells - normal muscle

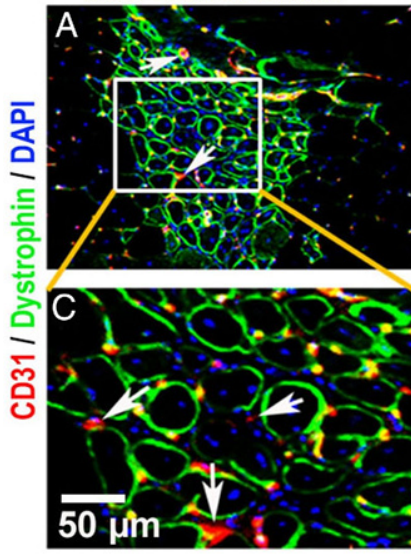

$\mathrm{E}$

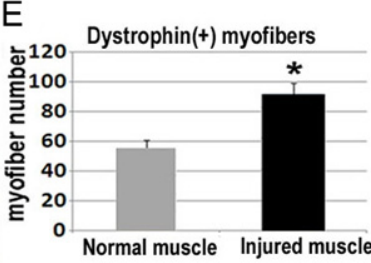

cells - injured muscle
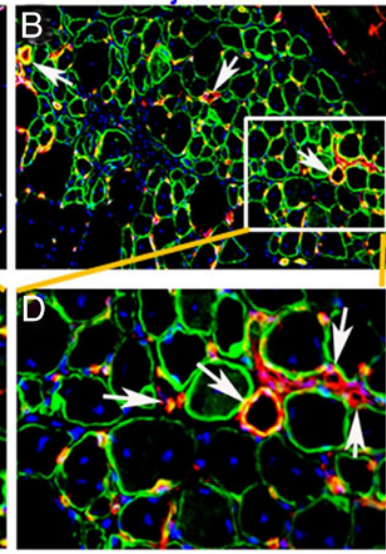

$\mathrm{F}$

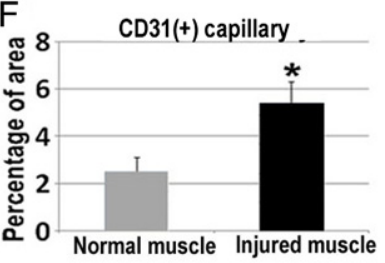

Figure 5. SASCs isolated from injured skeletal muscle demonstrated improved regenerative potential in MDX/SCID mice. Compared with cells isolated from noninjured muscle (A), SASCs isolated from injured muscle formed a greater number of dystrophin-positive myofibers and larger cell engraftment (B) at 3 weeks after transplantation of SASCs into gastrocnemius muscle in MDX/SCID mice. In addition, compared with the control group (C), more CD31-positive capillary structures were detected in the engraftments of SASCs isolated from injured muscle (D). Data in graphs $\mathbf{E}$ and $\mathbf{F}$ are from counting of cells or area with positive signal in images $\mathbf{A}$ and $\mathbf{B}$. $\mathbf{E}$ and F: Asterisk indicates that the value is significantly different from that of control noninjured muscle $(P<0.05)$.

ferentiation, respectively. Results demonstrated more cells positive for alkaline phosphatase in the osteogenic differentiation assay (Figure 4, F-J) and more cells positive for Oil Red $\mathrm{O}$ in the adipogenic differentiation assay (Figure 4, K-O) for SASCs from injured muscle compared with those from noninjured muscle. Therefore, SASCs from injured muscle seem to possess improved multiple differentiation potentials in vitro.

\section{SASCs from Injured Muscle Repair Dystrophic Muscle More Efficiently}

To verify the regenerative potential of the cells in repairing defective tissues, SASCs were also transplanted into dystrophic muscle of MDX/SCID mice to observe the progress of muscle regeneration. At 3 weeks after transplantation, SASCs from injured muscle formed a greater quantity of dystrophin-positive myofibers than did SASCs from noninjured muscle, and a larger area of cell engraftment in the muscle was also evident (Figure 5). In addition, there was greater CD31-positive capillary vasculature, or blood vessel formation, in the area of transplanted SASCs from injured muscle compared with SASCs from noninjured muscle (Figure 5, A-D). SASCs including MDSCs from noninjured muscles were able to release vascular endothelial growth factor and to induce angiogenesis in vivo. ${ }^{12}$ In addition, muscle stem cells can differentiate into the endothelial cell lineage.$^{16}$ It seems that SASCs from injured muscle may contribute to angiogenesis by both directly differentiating into endothelial cells and creating a favorable environment for angiogenesis by releasing vascular endothelial growth factor. ${ }^{4}$ Therefore, our in vivo results indicated that SASCs from injured muscle have improved regenerative potential in dystrophic muscle.

\section{Some Genes Related to Muscle Development or Stem Cell Regulation Are Up-Regulated in SASCs from Injured Muscle}

Injuries to the skeletal muscle modify the expression of many functional genes involved in the process of skeletal muscle development and regeneration. ${ }^{40,41}$ We suggest that the different characteristics of SASCs from noninjured muscle and injured muscle are related to their modified expression of certain functional genes. Using semiquantitative RT-PCR, we analyzed the expression of several genes related to stem cell multipotency, muscle development, and muscle regeneration to determine whether SASCs from noninjured muscle may express these genes and whether muscle injury may modify expression of these genes in SASCs. Genes included in the study were Notch1, STAT3, Msx1, Pax3, Pax7, MMP2, and MMP9 (Figure 6). Results of RT-PCR demonstrated that gene expression of Notch1, STAT3, MsX1, Pax3, and MMP2 was relatively up-regulated in SASCs from injured muscle (Figure 6).

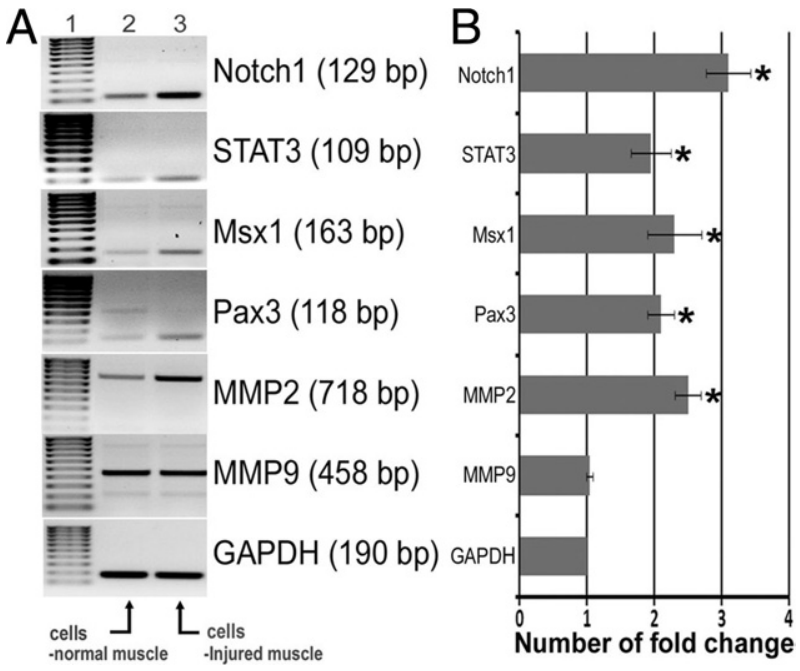

Figure 6. Comparison of gene expression in SASCs isolated from control noninjured and injured skeletal muscle in mice. $\mathbf{A}$ and B: Semiquantitative RT-PCR demonstrated that gene expression of Notch1, STAT3, Msx1, Pax3, and $M M P 2$, but not $M M P$ 9, was up-regulated in SASCs isolated from injured muscle compared with those from control noninjured muscle. GAPDH served as a control nonregulated gene. A: Lane 1 in the agarose gel is a DNA marker (100 bp); lanes 2 and 3 are RT-PCR-products of mRNA of SASCs isolated from control noninjured and injured murine skeletal muscle, respectively. Size of the PCR product of the genes is also shown. B: Statistical analysis was performed on the number of fold changes in gene expression compared with GAPDH. Asterisk indicates that the value is significantly different from that of control noninjured muscle $(P<0.05)$. 


\section{Discussion}

Compared with transplantation of myoblasts and satellite cells, transplantation of MDSCs from normal noninjured muscle is much more efficient because of their multiple advantages including multipotency, long-term proliferation, and capacity for self-renewal, antioxidation, and higher regeneration. ${ }^{6-8,42-44}$ In the present study, a large population of SASCs featuring a high percentage of MDSCs positive for Sca-1 and CD34 was efficiently isolated from injured skeletal muscles in mice. Compared with SASCs from noninjured muscle, SASCs from injured muscle were observed to have improved potential for proliferation, migration, multidifferentiation, and tissue regeneration. RT-PCR results indicated that these modified characteristics of SASCs from injured muscle may be linked to activation of some critical genes of muscle development and regeneration including Notch1, STAT3, Msx1, Pax3, and MMP2.

Previous studies have indicated that isolated mesenchymal stem cells from trauma-injured human muscle are similar to those from bone marrow and are multipotent in vitro owing to their differentiation capability into various tissues. ${ }^{45,46}$ Although they share many stem cell characteristics (ie, multipotency and Sca-1 expression), mesenchymal stem cells (fast-adhering) and SASCs are two distinct cell populations. ${ }^{45}$ To our knowledge, a direct characteristic comparison of muscle stem cells from noninjured and injured muscle had not yet been demonstrated. In the present study, SASCs from noninjured muscle, which are supposed to be quiescent at isolation, were directly compared with SASCs from injured muscle, which are supposed to be activated but undifferentiated at isolation. To study the undifferentiated SASCs before the occurrence of myogenic differentiation, SASCs were isolated from injured mouse muscle at 4 days after laceration injury. At that time, muscle degeneration is complete, inflammation and muscle stem cell proliferation are high, and muscle regeneration has just begun. ${ }^{23,24}$ Our results suggested that SASCs isolated from injured muscle may originate from activation of local SASCs in muscle, rather than circulating stem cells, because they are slow-adhering and tested negative for cell markers of circulating stem cells (ie, CD31 and CD45). ${ }^{31,37,38} \mathrm{~A}$ recent study has indicated that treatment using conditional transforming growth factor- $\beta 1$ could increase the stem cell-like cell population in myoblasts. ${ }^{20}$ Therefore, another possible source of these multipotent SASCs could be from dedifferentiation of mature muscle cells after stimulation by some specific growth factors such as transforming growth factor- $\beta 1$ released after muscle injury. ${ }^{20,47,48}$ Indeed, at 4 days after muscle injury, the biological concentration of transforming growth factor- $\beta 1$ in the injured muscle is beginning to increase, and it may result in a similar dedifferentiating effect on myoblasts in vivo, as it has in vitro. ${ }^{20,47}$

It was observed that SASCs isolated from injured muscle have enhanced proliferation and migration capacities and multidifferentiation potential in comparison with those isolated from control noninjured muscle. These characteristics are consistent with and critical to the important functions of mobilized stem cells in muscle repair. Improved proliferation capacity of SASCs generates a larger number of multipotent stem cells ready for efficient muscle regeneration, and improved migration capacity enables fast accumulation of multipotent stem cells at the site of injury. Meanwhile, improved multipotency would account for regeneration of injured skeletal muscle tissue by possibly differentiating into multiple cell types including myofibers, blood vessel-related cells (smooth muscle cells and endothelial cells), and neurons. ${ }^{12,19}$

At the molecular signaling level, Notch signaling functions either to maintain stemness or to initiate differentiation of multiple cell lineages, and ensures proper balance between stem cells and cells with a committed fate. ${ }^{49,50}$ Notch signaling is also essential for myogenic development and the regenerative potential of skeletal muscle. ${ }^{51}$ It has been suggested that the decreased regenerative potential of muscle stem cells (satellite cells) in aged muscle is due to diminished Notch signaling. ${ }^{51-53}$ STAT3 is a transcription factor essential for embryonic stem cell pluripotency, ${ }^{54,55}$ and STAT3 signaling may also be activated in skeletal muscle after acute exercise or injury. ${ }^{56,57}$ Moreover, STAT3 may be one of the downstream factors of Notch1 (Notch1-STAT3 signaling), which regulate stem cell characteristics. ${ }^{58} \mathrm{Msx} 1$ is a critical regulator of muscle development and regeneration that is primarily expressed in animals in the embryonic or fetal stage and is able to repress myogenic differentiation and maintain the undifferentiated status of stem cells. ${ }^{59-61}$ Both Pax3 and Pax7 are required for myogenic development, and are expressed in the somite; however, Pax7 is essential only for myogenesis after birth. ${ }^{62,63}$ During formation of muscles, Pax3 also has a critical function in facilitating long-range migration of muscle progenitor cells. ${ }^{63}$ Matrix metalloproteinases (MMPs) are also involved in myogenic differentiation, and their activities influence the migration capacity of muscle stem cells. ${ }^{27,64,65}$ MMP activity increases after muscle damage, ${ }^{66,67}$ and satellite cells have been recognized as muscle cells that express MMPs on activation. ${ }^{68}$ Increased MMP production results in efficient migration of satellite cells into injured areas. ${ }^{66,68}$

Up-regulated Notch1 and STAT3 signaling may contribute to improved proliferation capacity and multipotency of SASCs from injured muscle because both Notch1 and STAT3 are involved in stem cell maintenance and self-renewal. ${ }^{54,55,58,69,70}$ Activation of Notch1 and STAT3 signaling pathways is also required for efficient muscle regeneration, ${ }^{51,57}$ and their activation in SASCs from injured muscle may verify the highly regenerative potential and important function of this specific cell population in repairing injured muscle. In addition, the finding of activated Notch1 signaling in SASCs may suggest a promising contribution of the cells in therapeutic applications for regeneration of aged skeletal muscle. ${ }^{51,52}$ During the process of muscle repair, Pax3 and MMPs are important in regulating cell migration capacity. ${ }^{27,63,64}$ Specifically, MMP2 has an essential function in muscle cell proliferation and differentiation and muscle regeneration after injury. ${ }^{65,66,68}$ The up-regulated expression of Pax3 and MMP2 observed in SASCs from injured muscle 
may contribute to the improved migration capacity of these cells. In addition to functioning as an important regulator of limb and muscle development, ${ }^{59,71}$ Ms $\times 1$ has also been suggested as being able to promote dedifferentiation of muscle cells and to maintain the multipotency of stem cells. ${ }^{48,72,73}$ In a previous study, we observed that Msx1 overexpression in muscle cells resulted in a greatly improved ratio of cells positive for Sca- 1 to cells positive for CD34 (unpublished data). We also reported that traumatic injury is able to stimulate skeletal muscle cell dedifferentiation in vivo. ${ }^{48}$ Therefore, activation of Msx1 in SASCs isolated from injured muscle may help maintain the undifferentiated and proliferating status of the cells. Moreover, Msx1 may also perform a function similar to its purpose in embryonic and fetal muscle development, which is to instruct the migration and distribution of stem cells in injured muscle. ${ }^{59,60,71}$

In summary, SASCs isolated from injured muscle using the preplate technique are highly proliferative, multipotent, and regenerative. These results may reflect the characterization of many other types of injured stem cells, which indicates that environmental factors have a critical role in modifying stem cell characteristics and behavior.

\section{Acknowledgments}

We thank Jonathan Lucas, Kyle Holden, Alison Logar, Kiley Murray, and Wen Xu for technical or editing assistance, and Dr. Xiaoping Chen for helpful suggestions.

\section{References}

1. Zammit PS, Partridge TA, Yablonka-Reuveni Z: The skeletal muscle satellite cell: the stem cell that came in from the cold. J Histochem Cytochem 2006, 54:1177-1191

2. Skuk D, Tremblay JP: Myoblast transplantation: the current status of a potential therapeutic tool for myopathies. J Muscle Res Cell Motil 2003, 24:285-300

3. Crisan M, Yap S, Casteilla L, Chen CW, Corselli M, Park TS, Andriolo G, Sun B, Zheng B, Zhang L, Norotte C, Teng PN, Traas J, Schugar R, Deasy BM, Badylak S, Buhring HJ, Giacobino JP, Lazzari L, Huard J, Peault B: A perivascular origin for mesenchymal stem cells in multiple human organs. Cell Stem Cell 2008, 3:301-313

4. Deasy BM, Feduska JM, Payne TR, Li Y, Ambrosio F, Huard J: Effect of VEGF on the regenerative capacity of muscle stem cells in dystrophic skeletal muscle. Mol Ther 2009, 17:1788-1798

5. Zheng B, Cao B, Crisan M, Sun B, Li G, Logar A, Yap S, Pollett JB, Drowley L, Cassino T, Gharaibeh B, Deasy BM, Huard J, Peault B: Prospective identification of myogenic endothelial cells in human skeletal muscle. Nat Biotechnol 2007, 25:1025-1034

6. Qu-Petersen Z, Deasy B, Jankowski R, Ikezawa M, Cummins J, Pruchnic R, Mytinger J, Cao B, Gates C, Wernig A, Huard J: Identification of a novel population of muscle stem cells in mice: potential for muscle regeneration. J Cell Biol 2002, 157:851-864

7. Gharaibeh B, Lu A, Tebbets J, Zheng B, Feduska J, Crisan M, Peault $\mathrm{B}$, Cummins J, Huard J: Isolation of a slowly adhering cell fraction containing stem cells from murine skeletal muscle by the preplate technique. Nat Protoc 2008, 3:1501-1509

8. Torrente Y, Tremblay JP, Pisati F, Belicchi M, Rossi B, Sironi M, Fortunato F, El Fahime M, D'Angelo MG, Caron NJ, Constantin G, Paulin D, Scarlato G, Bresolin N: Intraarterial injection of musclederived CD34(+)Sca-1(+) stem cells restores dystrophin in MDX mice. J Cell Biol 2001, 152:335-348

9. Li Y, Pan H, Huard J: Isolating stem cells from soft musculoskeletal tissues. J Vis Exp 2010, doi: 10.3791/2011
10. Rando TA, Blau HM: Primary mouse myoblast purification, characterization, and transplantation for cell-mediated gene therapy. J Cell Biol 1994, 125:1275-1287

11. Oshima H, Payne TR, Urish KL, Sakai T, Ling $Y$, Gharaibeh B, Tobita K, Keller BB, Cummins JH, Huard J: Differential myocardial infarct repair with muscle stem cells compared to myoblasts. Mol Ther 2005 , 12:1130-1141

12. Payne TR, Oshima H, Okada M, Momoi N, Tobita K, Keller BB, Peng $\mathrm{H}$, Huard J: A relationship between vascular endothelial growth factor, angiogenesis, and cardiac repair after muscle stem cell transplantation into ischemic hearts. J Am Coll Cardiol 2007, 50:16771684

13. Corsi KA, Pollett JB, Phillippi JA, Usas A, Li G, Huard J: Osteogenic potential of postnatal skeletal muscle-derived stem cells is influenced by donor sex. J Bone Miner Res 2007, 22:1592-1602

14. Kwon D, Kim Y, Pruchnic R, Jankowski R, Usiene I, de Miguel F, Huard J, Chancellor MB: Periurethral cellular injection: comparison of muscle-derived progenitor cells and fibroblasts with regard to efficacy and tissue contractility in an animal model of stress urinary incontinence. Urology 2006, 68:449-454

15. Chermansky CJ, Tarin T, Kwon DD, Jankowski RJ, Cannon TW, de Groat WC, Huard J, Chancellor MB: Intraurethral muscle-derived cell injections increase leak point pressure in a rat model of intrinsic sphincter deficiency. Urology 2004, 63:780-785

16. Arriero M, Brodsky SV, Gealekman O, Lucas PA, Goligorsky MS: Adult skeletal muscle stem cells differentiate into endothelial lineage and ameliorate renal dysfunction after acute ischemia. Am J Physiol Renal Physiol 2004, 287:F621-F627

17. Li Y, Huard J: Differentiation of muscle-derived cells into myofibroblasts in injured skeletal muscle. Am J Pathol 2002, 161:895-907

18. Kuroda R, Usas A, Kubo S, Corsi K, Peng H, Rose T, Cummins J, Fu $\mathrm{FH}$, Huard $\mathrm{J}$ : Cartilage repair using bone morphogenetic protein 4 and muscle-derived stem cells. Arthritis Rheum 2006, 54:433-442

19. Arsic N, Mamaeva D, Lamb NJ, Fernandez A: Muscle-derived stem cells isolated as non-adherent population give rise to cardiac, skeletal muscle and neural lineages. Exp Cell Res 2008, 314:1266-1280

20. Mu X, Li Y: Conditional TGF-beta1 treatment increases stem cell-like cell population in myoblasts. J Cell Mol Med 2011;15:679-690

21. Polesskaya A, Seale $P$, Rudnicki MA: Wnt signaling induces the myogenic specification of resident CD45+ adult stem cells during muscle regeneration. Cell 2003, 113:841-852

22. Cantini M, Massimino ML, Catani C, Rizzuto R, Brini M, Carraro U: Gene transfer into satellite cell from regenerating muscle: bupivacaine allows beta-Gal transfection and expression in vitro and in vivo. In Vitro Cell Dev Biol 1994, 30A:131-133

23. Huard J, Li Y, Fu FH: Muscle injuries and repair: current trends in research. J Bone Joint Surg Am 2002, 84-A(5):822-832

24. Jarvinen TA, Jarvinen TL, Kaariainen M, Kalimo H, Jarvinen M: Muscle injuries: biology and treatment. Am J Sports Med 2005, 33:745-764

25. Sicinski P, Geng Y, Ryder-Cook AS, Barnard EA, Darlison MG, Barnard PJ: The molecular basis of muscular dystrophy in the MDX mouse: a point mutation. Science 1989, 244:1578-1580

26. Bedair H, Liu TT, Kaar JL, Badlani S, Russell AJ, Li Y, Huard J: Matrix metalloproteinase-1 therapy improves muscle healing. J Appl Physiol 2007, 102:2338-2345

27. Wang W, Pan H, Murray K, Jefferson BS, Li Y: Matrix metalloproteinase-1 promotes muscle cell migration and differentiation. Am J Pathol 2009, 174:541-549

28. Mu X, Urso ML, Murray K, Fu F, Li Y: Relaxin regulates MMP expression and promotes satellite cell mobilization during muscle healing in both young and aged mice. Am J Pathol 2010, 177:2399-2410

29. Zuk PA, Zhu M, Mizuno H, Huang J, Futrell JW, Katz AJ, Benhaim P, Lorenz HP, Hedrick MH: Multilineage cells from human adipose tissue: implications for cell-based therapies. Tissue Eng 2001, 7:211-228

30. Zheng B, Cao B, Li G, Huard J: Mouse adipose-derived stem cells undergo multilineage differentiation in vitro but primarily osteogenic and chondrogenic differentiation in vivo. Tissue Eng 2006, 12:18911901

31. Seale P, Ishibashi J, Scime A, Rudnicki MA: Pax7 is necessary and sufficient for the myogenic specification of CD45+: Sca1+ stem cells from injured muscle. PLoS Biol 2004, 2:E130

32. Kolf CM, Cho E, Tuan RS: Mesenchymal stromal cells: biology of adult mesenchymal stem cells; regulation of niche, self-renewal and differentiation. Arthritis Res Ther 2007, 9:204 
33. Halevy O, Novitch BG, Spicer DB, Skapek SX, Rhee J, Hannon GJ, Beach D, Lassar AB: Correlation of terminal cell cycle arrest of skeletal muscle with induction of p21 by MyoD. Science 1995, 267 1018-1021

34. Hawke TJ, Meeson AP, Jiang N, Graham S, Hutcheson K, DiMaio JM, Garry DJ: p21 is essential for normal myogenic progenitor cell function in regenerating skeletal muscle. Am J Physiol Cell Physiol 2003 285:C1019-C1027

35. Cheng $T$, Rodrigues $N$, Shen $H$, Yang $Y$, Dombkowski D, Sykes M, Scadden DT: Hematopoietic stem cell quiescence maintained by p21cip1/waf1. Science 2000, 287:1804-1808

36. Kippin TE, Martens DJ, van der Kooy D: p21 loss compromises the relative quiescence of forebrain stem cell proliferation leading to exhaustion of their proliferation capacity. Genes Dev 2005, 19:756-767

37. DeLisser HM, Christofidou-Solomidou M, Strieter RM, Burdick MD, Robinson CS, Wexler RS, Kerr JS, Garlanda C, Merwin JR, Madri JA, Albelda SM: Involvement of endothelial PECAM-1/CD31 in angiogenesis. Am J Pathol 1997, 151:671-677

38. McKinney-Freeman SL, Jackson KA, Camargo FD, Ferrari G, Mavilio F, Goodell MA: Muscle-derived hematopoietic stem cells are hematopoietic in origin. Proc Natl Acad Sci USA 2002, 99:1341-1346

39. Weiss A, Leinwand LA: The mammalian myosin heavy chain gene family. Annu Rev Cell Dev Biol 1996, 12:417-439

40. Summan M, McKinstry M, Warren GL, Hulderman T, Mishra D, Brumbaugh K, Luster MI, Simeonova PP: Inflammatory mediators and skeletal muscle injury: a DNA microarray analysis. J Interferon Cytokine Res 2003, 23:237-245

41. Haslett JN, Kunkel LM: Microarray analysis of normal and dystrophic skeletal muscle. Int J Dev Neurosci 2002, 20:359-365

42. Urish KL, Vella JB, Okada M, Deasy BM, Tobita K, Keller BB, Cao B, Piganelli JD, Huard J: Antioxidant levels represent a major determinant in the regenerative capacity of muscle stem cells. Mol Biol Cell 2009, 20:509-520

43. Quintero AJ, Wright VJ, Fu FH, Huard J: Stem cells for the treatment of skeletal muscle injury. Clin Sports Med 2009, 28:1-11

44. Peault B, Rudnicki M, Torrente Y, Cossu G, Tremblay JP, Partridge T, Gussoni E, Kunkel LM, Huard J: Stem and progenitor cells in skeletal muscle development, maintenance, and therapy. Mol Ther 2007 15:867-877

45. Jackson WM, Aragon AB, Djouad F, Song Y, Koehler SM, Nesti LJ, Tuan RS: Mesenchymal progenitor cells derived from traumatized human muscle. J Tissue Eng Regen Med 2009, 3:129-138

46. Nesti LJ, Jackson WM, Shanti RM, Koehler SM, Aragon AB, Bailey JR, Sracic MK, Freedman BA, Giuliani JR, Tuan RS: Differentiation potential of multipotent progenitor cells derived from war-traumatized muscle tissue. J Bone Joint Surg Am 2008, 90:2390-2398

47. Li Y, Foster W, Deasy BM, Chan Y, Prisk V, Tang Y, Cummins J, Huard $\mathrm{J}$ : Transforming growth factor-beta1 induces the differentiation of myogenic cells into fibrotic cells in injured skeletal muscle: a key event in muscle fibrogenesis. Am J Pathol 2004, 164:1007-1019

48. Mu X, Peng H, Pan H, Huard J, Li Y: Study of muscle cell dedifferentiation after skeletal muscle injury of mice with a Cre-Lox system. PLoS One 2011, 6:e16699

49. Bray SJ: Notch signalling: a simple pathway becomes complex. Nat Rev Mol Cell Biol 2006, 7:678-689

50. Boni A, Urbanek K, Nascimbene A, Hosoda T, Zheng H, Delucchi F, Amano K, Gonzalez A, Vitale S, Ojaimi C, Rizzi R, Bolli R, Yutzey KE, Rota M, Kajstura J, Anversa P, Leri A: Notch1 regulates the fate of cardiac progenitor cells. Proc Natl Acad Sci USA 2008, 105:15529-15534

51. Conboy IM, Conboy MJ, Smythe GM, Rando TA: Notch-mediated restoration of regenerative potential to aged muscle. Science 2003 , 302:1575-1577

52. Carlson ME, Hsu M, Conboy IM: Imbalance between pSmad3 and Notch induces CDK inhibitors in old muscle stem cells. Nature 2008 , 454:528-532
53. Carey KA, Farnfield MM, Tarquinio SD, Cameron-Smith D: Impaired expression of Notch signaling genes in aged human skeletal muscle. J Gerontol A Biol Sci Med Sci 2007, 62:9-17

54. Raz R, Lee CK, Cannizzaro LA, d'Eustachio P, Levy DE: Essential role of STAT3 for embryonic stem cell pluripotency. Proc Natl Acad Sci USA 1999, 96:2846-2851

55. Hall J, Guo G, Wray J, Eyres I, Nichols J, Grotewold L, Morfopoulou S, Humphreys P, Mansfield W, Walker R, Tomlinson S, Smith A: Oct4 and LIF/Stat3 additively induce Kruppel factors to sustain embryonic stem cell self-renewal. Cell Stem Cell 2009, 5:597-609

56. Trenerry MK, Carey KA, Ward AC, Cameron-Smith D: STAT3 signaling is activated in human skeletal muscle following acute resistance exercise. J Appl Physiol 2007, 102:1483-1489

57. Kami K, Senba E: In vivo activation of STAT3 signaling in satellite cells and myofibers in regenerating rat skeletal muscles. J Histochem Cytochem 2002, 50:1579-1589

58. Androutsellis-Theotokis A, Leker RR, Soldner F, Hoeppner DJ, Ravin R, Poser SW, Rueger MA, Bae SK, Kittappa R, McKay RD: Notch signalling regulates stem cell numbers in vitro and in vivo. Nature 2006, 442:823-826

59. Houzelstein D, Auda-Boucher G, Cheraud Y, Rouaud T, Blanc I, Tajbakhsh S, Buckingham ME, Fontaine-Perus J, Robert B: The homeobox gene Msx1 is expressed in a subset of somites, and in muscle progenitor cells migrating into the forelimb. Development 1999, 126:2689-2701

60. Han M, Yang X, Farrington JE, Muneoka K: Digit regeneration is regulated by Msx1 and BMP4 in fetal mice. Development 2003, 130:5123-5132

61. Kumar A, Velloso CP, Imokawa Y, Brockes JP: The regenerative plasticity of isolated urodele myofibers and its dependence on MSX1. PLoS Biol 2004, 2:E218

62. Relaix F, Rocancourt D, Mansouri A, Buckingham M: A Pax3/Pax7dependent population of skeletal muscle progenitor cells. Nature 2005, 435:948-953

63. Relaix F, Rocancourt D, Mansouri A, Buckingham M: Divergent functions of murine Pax3 and Pax7 in limb muscle development. Genes Dev 2004, 18:1088-1105

64. Nishimura T, Nakamura K, Kishioka Y, Kato-Mori Y, Wakamatsu J, Hattori A: Inhibition of matrix metalloproteinases suppresses the migration of skeletal muscle cells. J Muscle Res Cell Motil 2008, 29:37-44

65. Lluri G, Jaworski DM: Regulation of TIMP-2, MT1-MMP, and MMP-2 expression during C2C12 differentiation. Muscle Nerve 2005, 32: 492-499

66. Carmeli E, Moas M, Reznick AZ, Coleman R: Matrix metalloproteinases and skeletal muscle: a brief review. Muscle Nerve 2004, 29:191-197

67. Carmeli E, Moas M, Lennon S, Powers SK: High intensity exercise increases expression of matrix metalloproteinases in fast skeletal muscle fibres. Exp Physiol 2005, 90:613-619

68. Kherif S, Lafuma C, Dehaupas M, Lachkar S, Fournier JG, VerdiereSahuque M, Fardeau M, Alameddine HS: Expression of matrix metalloproteinases 2 and 9 in regenerating skeletal muscle: a study in experimentally injured and mdx muscles. Dev Biol 1999, 205:158170

69. Stier S, Cheng T, Dombkowski D, Carlesso N, Scadden DT: Notch1 activation increases hematopoietic stem cell self-renewal in vivo and favors lymphoid over myeloid lineage outcome. Blood 2002, 99:2369-2378

70. Collesi C, Zentilin L, Sinagra G, Giacca M: Notch1 signaling stimulates proliferation of immature cardiomyocytes. J Cell Biol 2008, 183:117-128

71. Reginelli AD, Wang YQ, Sassoon D, Muneoka K: Digit tip regeneration correlates with regions of Msx1 ( Hox 7) expression in fetal and newborn mice. Development 1995, 121:1065-1076

72. Lee H, Habas R, Abate-Shen C: MSX1 cooperates with histone $\mathrm{H} 1 \mathrm{~b}$ for inhibition of transcription and myogenesis. Science 2004, 304: 1675-1678

73. Odelberg SJ, Kollhoff A, Keating MT: Dedifferentiation of mammalian myotubes induced by $\mathrm{msx}$. Cell 2000, 103:1099-1109 